\title{
AVETISYAN ANI
}

\section{THE COLLECTION OF OTTOMAN TURKISH MANUSCRIPTS OF THE MATENADARAN AND THE DESCRIPTION METHODOLOGY}

The Mashtots Institute of Ancient Manuscripts "Matenadaran" is one of the richest manuscript depositories of the world. It holds 20,310 unities in different languages (Old Armenian, Ottoman Turkish with Armenian letters, Georgian, Latin, Greek, Hebrew, French, Syriac, Hindu etc.). A valuable part of them is the Collection of Islamic manuscripts which consist of 2,715 codices in Arabic, Persian and Ottoman Turkish. The total number of Ottoman Turkish manuscripts is 400 .

The first descriptions of Islamic Manuscripts of Matenadaran Collection consist of twenty-three manuscript registers.

Previously, these manuscript registers were entitled List of Manuscripts in Arabic - Persian - Uzbek - Azerbaijani ( فهرست كتب و دستخط عربى و فارسى و (j) اوزبكى و آزربايجانى ; later the title was concretized as List of Manuscripts in Arabic Script. The first cataloguer's name is Hovhannes Ghukasyan, and the date of the cataloguing is 1948. This information is written in the margine of the title-page of the first manuscript register ( 1991 در سنة (ميلادىاز طرف اوهانس خوقسيان منظوم شد). If the name of the first cataloguer and the date of the work beginning are mentioned, nevertheless, there is no mention in the next registers about the other cataloguers and the chronological course of the work and its conclusion.

Subsequently, to achieve our task of creating a new and exhaustive catalogue of the Matenadaran Ottoman Turkish manuscripts. First of all we started the review of the available manuscripts in order to get general and particular notions about them, appreciate the efforts made previously with the aim of choose and utilize everything useful.

The manuscripts have been described by diverse persons at different times. Describers, even if they mastered necessary languages (Arabic, Persian or Ottoman Turkish), did temporary work, either because they didn't have codicological ability or because they were short in time. Descriptions of manuscripts are bilingual: Persian or Arabic with parallel translation into Armenian. 
Descriptions of Ottoman Turkish manuscripts in abovementioned registers are done quickly and very generally, without giving any notion about the manuscripts integral image.

Notices of written and unwritten pages quantities contain errors. Aspectual and qualitative peculiarities of the subjects are not mentioned; often only "paper" or "parchment" are specified. Sometimes, speaking about the form of script (one-columnar or two-columnar), they introduce as well the calligraphy and the number of lines (the number of lines seems to be cited only according to the first page lines). Only the colour of the binding is mentioned. There is no mention of the fly-leaves. Dates of copy and further colophons, pen tryings (pen trials), seals and watermarks are never mentioned. The manuscripts' state is appreciated only by the terms "satisfying", "good", "very good" and "restored". The contents are stated only by one-word notices: "religious", "grammar", "poetry", "jurisprudence", "logics", "medicine" and so on.

Sometimes the language of the manuscript is wrongly determined: Persian and Arabic manuscripts are mentioned as Ottoman Turkish ones and vice-versa.

Thus, this review of the manuscripts written with Arabic script allowed stating the approximate quantity of Ottoman Turkish manuscripts. The manuscripts' description level and their contents are specified.

Subsequently, manuscripts were grouped according to their contents: literature, history, religion, jurisprudence, medecine, calendar theory, versification, rhetoric, astronomy, cosmology, arithmetic, geometry, grammar, as well as dictionaries, talismans, correspondence, ferayiz (legislation of heritage distribution) and etc.

Having at our disposal the registers' data, using the guidance of foreign catalogues ${ }^{1}$ and possibilities offered by Internet information,

${ }^{1}$ Rieu Ch., Catalogue of the Turkish Manuscripts in British Museum, Osnabrück, 1978; Catalogue of Turkish Manuscripts in the Library of the Hungarian Academy of Sciences, Composed by Ismail Parlatir, György Hazai and Barbara KellnerHeinkele, 2007; Flügel G., Die arabischen, persischen, türkischen Handschriften der k.u.k. Hofbibliothek zu Wien I, New York, 1977; Türkiye yazmalar Toplu Kataloğu ISPARTA, Milli Kütuphane Basimevi, Ankara, 2000; Şadi Aydin, Iran Kütüphaneleri Türkçe Yazmalar Kataloğu, Timaş Yayinari, Istanbul, 2008. 
nevertheless, the description and cataloguing of Ottoman Turkish manuscripts was done by using the model of Armenian manuscripts description and cataloguing in following points: classmark of the manuscript, title, place of copy, date of copy, copiest, author, number of folios, unwritten leaves, writing material, Ink, dimensions, script, number of lines, catchwardes, binding, fly-leaves, state, content, scribal colophons, later colophons, ownership notes, seals, stamped seals, pen tryings, notes, miniatures and etc.

As an example, let us cite some items of description.

In the rubric "writing material", we note kind of the paper, if it has waterlines, mistara (stamped lines), watermarks, leaves are numbered and cited one by one.

In the rubric "binding" we note the material of it (leather, artificial leather, glazed-cloth, etc.), its colour; the décoration, the doublure (paper, decorated paper with floral design, marbled paper etc.) are specified.

In the rubric "fly-leaves" we number fly-leaves with Armenian letters. Their quantity, letter unities and the kind of paper are noted.

In the rubric "state" we write down the general state of the manuscript; wears and tears of the binding, the leaves and the writing field are noted; we also note if the manuscript is incomplete, if it had been restored, the quality of restoration is defined and so on.

In the rubric "scribal colophons", "later colophons", we cite the colophons, their pages and sometimes their translations into Armenian.

In the rubric "seals", "stamping" we note the page, the form, the time of the seals, as well as the ink colour and the seal decipherment. Exterior data are written down in brackets, the decipherment in quotation marks.

In the rubric "pen trying" we note the pages and if it has any important content, it is written down.

In the rubric "notes" we group the library notes, names of donators, which are written on pieces of other paper and pasted on doublure of the main manuscript, as well as manuscript notes of other scholars having studied it.

In the rubric "miniature" we note its kind (vignette, half-vignette, frontispiece, marginal ornament and so on), the page and colours used in illumination. 
In the rubric "content" we enumerate pages of the manuscript text or texts, then give a summary in Armenian, citing the beginning and the end of the Ottoman Turkish text. If the text consists of chapters and the chapters have also parts, all pages are noted.

Sometimes, there are marginal notes which are usually supplements to the text. They are cited with their page numbers; if there is any foreign catalogue in which another copy of the manuscript is described, we cite the catalogue, the manuscript's number and page. If there are works devoted to the text: articles or studies, their sources are cited as well. Supplementary information about the text is written down with their source.

The collection of Ottoman Turkish manuscripts kept in the Matenadaran dates back mostly to the $16^{\text {th }}, 17^{\text {th }}, 18^{\text {th }}$ and $19^{\text {th }}$ centuries.

At present, the most ancient Ottoman Turkish manuscript of the Matenadaran is the MS No. 196, dated in AH 972 /AD 1564-1565 (Colophone, f. 174a).

The manuscript contains two works. The first one is devoted to the variants of the vowel 1 meanings in Persian (كماله يائيه فى لسان الفرسى من مولفات (كمال ياشاز اده رحمه الله (ff. 1b-26b). The author of the work is not mentioned in the manuscript. The supposition that the author is Kemāl Pasha Zādeh (AH 940/AD 1534), i.e. Mawlawīyah Imam Shems ud-Dīn Ahmed B. Suleimān B. $K e m \bar{a} P^{2}$ is confirmed by comparison with descriptions in foreign catalogues ${ }^{3}$.

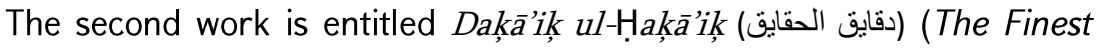

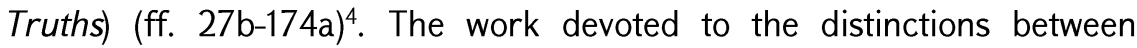

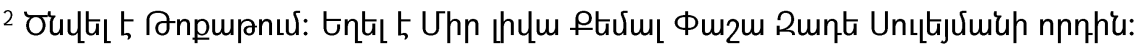

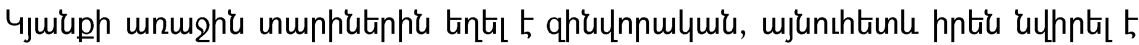

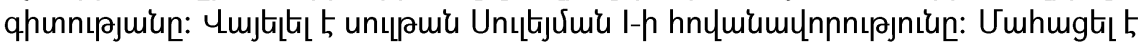

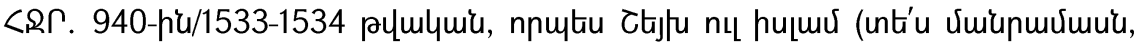
Rieu Ch., Catalogue of the Turkish Manuscripts in the British Museum, Or. 36, Osnabrück, 1978, p. 142):

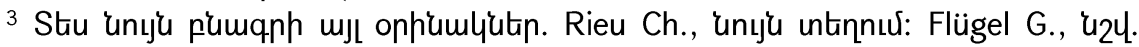
$u_{2}$ u., $5_{2}$ 131-132:

4 Stu unıju pumqnh uJ ophimulyutin. Rieu Ch., Catalogue of the Turkish Manuscripts in the British Museum Add. 7887, pp. 141-142; Catalogue of the 
Persian homonyms and synonyms. In the Preface the author writes, that his Risāle (Treatise) studies the nice words, which beautify the literary speech (f. 28a). The Turkish commentary is expanded with numerous Persian verses ${ }^{5}$ of poets Hāẩiz̆, Firdevsi, Sa'adī, Nī̄āmi and etc., sometimes verses in Arabic. The words' examples have not given in alphabetical order, often simultaneously is given the Arabic and Ottoman Turkish versions of the words. From the Preface it is obvious that the work is dedicated to Grand Vezir Ibrāhīm Pasha of Sulțān Suleimān I (f. 28a). The author of the work is Kemāl Pasha Zādeh as well as descriptions in foreign catalogues confirm it. In some foreign catalogues the Treatise mantioned as Persian-Turkish Dictionary ${ }^{6}$.

In the previous description of the Matenadaran MSS NN 334 and 394 have been considered as only Persian manuscripts. Studying them we noticed that Persian passages of the manuscript are followed by passages in Ottoman Turkish and Arabic.

The MS No. 334 is a trilingual (Persian, Ottoman Turkish, Arabic) work in prose and verse, devoted to the Battle of Kerbelā and the Martyrdom of Shiite Imāms. It was written in AH 1301/AD 1883-1884 (Colophons, ff. 41a, 59a, 79a, 190b).

Persian Manuscripts in the British Museum, Volume II, Add. 7887, p. 514; Flügel G., 'u24. u$_{2}$ łu., $t_{2}$ 130-131: Schmidt J., Catalogue of Turkish Manuscripts in the Library of Leiden University and Other Collections in the Netherlands, vol. I, Cod. Or. 860, Cod. Or. 962, Leiden, 2000, pp. 300-301, pp. 360-361; Şadi Aydın, Iran Kütüphaneleri Türkçe Yazmalar Kataloğu, Nr. 3274, Istanbul, 2008, s. 26; Şadi Aydin, u24. u2łu., Tabriz Milli Kütüphane Koleksyonu Nr. 2714, ss. 41-42; Sazman-i LūğatNâme-i Dehhuda Kūtūphanesi Nr. 45, Nr. 2543 s. 49: Tahran Ūniversitesi HukukSiyasi Bilgiler ve Iktisad Fakūltesi, Nr. F-2386, s. 67; Islami Şura Meclisi Kūtūphanesi I, Nr. 15251, s. 75; Medrese-i Ali-i Şehid Mutahhari Kütüphanesi, Nr. 101, s. 88; Gūlpaygani (Ayetullah) Kūtūphanesi, Nr. 9/131, s.110; Türkiye Yazmalar Toplu Kataloğu, 34/III, Istanbul Süleymaniye Kütüphanesi, 34 Sü-Hü 372, Ankara 1987, s. 168:

${ }^{5}$ Beit, Rubā'i, Misrah u mృlı:

6 Flügel G., u24. m2łu., to 130-131: Şadi Aydin, Iran Kütüphaneleri Türkçe Yazmalar Kataloğu, Istanbul, 2008; Türkiye Yazmalar Toplu Kataloğu, 34/III, 34 Sü-Hü 372, s. 168. 
The MS No. 394 is a trilingual work which describes the Life and Martyrdom of Shiite Imāms in prose and verse. The work begins by an Arabic preface in which the author notes that described misfortunes occurred at the time of Prophet Muhammed and author utilized tales of the Qur'ān, as well as works in Arabic, Persian and Ottoman Turkish. The Ottoman Turkish part of the manuscript consists of religious Kā̦s dehs praising God, Prophet Mụ̣ammed, Imām Ḥusein and narrating the tragical events at Kerbelā. The Kaiș dehs not separated by titles and are followed by Persian Kaișdehs of the same content. The manuscript dated AH 1289/AD 1872-1873 and the author is Javad Huseini (Colophon, f. 2a). The manuscript is incomplete at the end. Two manuscripts (MSS NN 393 and 394) are joined in one volume ${ }^{7}$.

Among described Ottoman Turkish manuscripts, sixteen have Literary contents $^{8}$; those are Verse Collections (Divan) by Turkish poets of the $16^{\text {th }}$ - 17 ${ }^{\text {th }}$ centuries: Veisi (MS No. 197), Nef'i (MS No. 223), Bāḳi (MS No. 321) $)^{9}$, Fehīm (MS No. 323)10; The poem Khusrev and Shīnnn (خسرو و شيرين) by Sheikhi (MS No. 302)"11 The Story of Ten Birds (حكايه ده مرغ شمسى) by Shemsi (MS No. 646) copied by 'Omer ibn 'Osman al Hakīr (Colophone, f. 34a); The Story of Forty Veziers (حكايه' قرق وزير) (MSS NN 563, 1889); Khairiye or Khairi Nāmeh (خيريه) (MS No. 296 (ff. 1b-50a), MS No. 747), Tuḥfeh i Dilkesh (تحفه' دلكش) (MS No. 296, 51b-109a) and Khayrâbâd ( خير آباد')

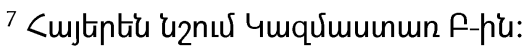

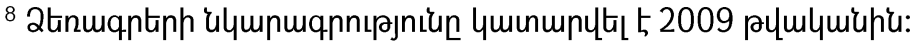

9 Stíu unyju pumqnh mJ ophiumlititn. Rieu Ch., Catalogue of the Turkish Manuscripts in the British Museum, Add. 7922, pp. 187-188, Add. 25.423, pp. 188-189; Arabische, Türkische und Persische Handschriften der Universitätsbibliothek in Bratislava, 1961, Bratislava, S. 340-341; Schmidt J., Catalogue of Turkish Manuscripts in the Library of Leiden University and Other Collections in the Netherlands, Volume I, Leiden, 2000, Cod. Or. 837, pp. 282284:

10 St'u uny'u p'umqnh mı oph'umlyutp. Rieu Ch., Catalogue of the Turkish Manuscripts in the British Museum, Add. 7924, p. 196; Flügel G., 'u24. u2łu., t2 659-660.

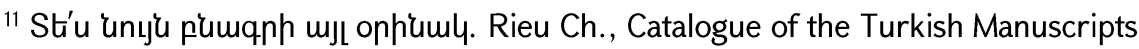
in the British Museum, Add. 7906, pp. 165-166. 
(النابى مرحوم (MS No. 297 (ff. 1b-56b), MS No. 2014 (ff. 3b-73b)) Mesnevis (Poems) by Nābi; Turkish prose translations of Nizāami's Poems' Iskender

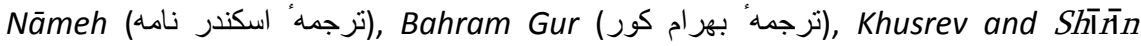

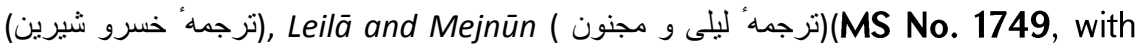
miniatures); the Tale Shahzādeh (هذا حكايت شاهز اده عانشق غرنيب) by A' 'shik Garib (MS No. 1262), written in AH 1245 /AD 1829-1830 (Colophone, f. 24a); incomplete copy of Verse Book by an anonymous author (MS No. 1861); a Note-book of Fairy Tales (دفتر حكايات و روايات) (MS No. 413).

Ferayiz (legislation of heritage distribution) are numerous among Turkish manuscripts. At present, only two of them (MSS NN 985 and 1454) have been thematically studied. MS No. 985 is an Interpretation of Ferayiz (شرح الفرايض) dated AH 1061/AD 1650-51 by the scribe Musțafa, known as Mawlawìyah Husein Efendi Zādeh (Colophone, f. 74a). In Preface he writes that the work was translated into Turkish by Dursun Zādeh as close as possible to the original, correctly describing and explaining terms, and preserving the words' order of the original. At the end of the work the scribe notes that Ibn Dursun collected valuable documents about issues of heritage distribution and completed the work, which was written in $\mathrm{AH}$ 1008 /AD 1599-1600 (Colophones, ff. 73b, 74a).

The MSS NN 412, 436, 633, 1803 and 2110 of the Matenadaran Collection are known as Calendars of Darendevi ${ }^{12}$.The title is written in the lower part of the frontispiece of the MS No. 633. While comparing the MS No. 633 with the MSS NN 412, 436, 1803 and 2110 noticing structure and contents similarity, we can state without hesitation that the codices are Calendars of Darendevi (هiا روزنامة دارندوى) of the $18^{\text {th }}$ and $19^{\text {th }}$ centuries as well. These manuscriptsare ribbon-like, written on paper or parchment with Ruq'a and Naskh scripts, and consist of thirteen tables.

The MSS NN 140, 228, 299, 346, 656 and 1096 are attracting attention by their interesting contents.

MS No. 140 contains a copy of Jevāhir Nāmeh (جواحر نامه) and was

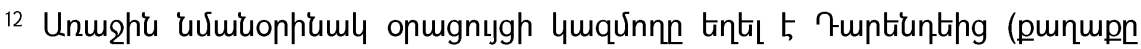

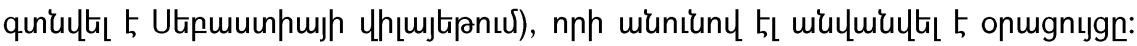
4tinghupu untindnnn tints 5 nर्ú Uthútin (St'u Турецкій Въчный Календарь Дарэндэви, С. Петербургь, 1883, стр. 23). 
written in the $19^{\text {th }}$ century. It consists of 32 chapters, each one of which is speaking about one precious stone. Stones are presented by their names, kind, value, use, place of discovery, colour and so on. As the manuscript is incomplete, it is difficult to give any precise information about its author and copiest.

The MS No. 228 contains a List of Ottoman Sultān Names (اسامى شريفه لر); copied in AH 1314/AD 1896-1897 by Mirza 'Abd ul Ḥasan Kā̄zz Zādeh at Tekie (Colophone, 6a). The manuscript is a list of Ottoman Sulțāns from the beginning of the Ottoman Empire up to the 31 st Sulțān 'Abd ul-Mejid Hasan ibn al Suțān al Gazi Mahmud Hasan (AH 1299/AD 1820). It gives the dates $(\mathrm{AH})$ of birth, enthronization and death (or destitution) of each of Sultāns, the duration of their ruling and life, as well as data about their mausoleums ${ }^{13}$.

The MS No. 299 is a manuscript of the $19^{\text {th }}$ century about the administrative division of the Ottoman Empire into 24 Vilayets and 64 Sanjaks, and smaller administrative unities included in the text (ff.1b-22b), the List of Kapudan Pasha's and Others' Islands (ff. 22b-23a); the Examples of Letters' beginnings dedicated to Sulțāns (ff. 23b-25a).

The MS No. 346 is again a manuscript of the $19^{\text {th }}$ century, it contains a Genealogy (سلسله نامه) with genealogical trees beginning with Adam and reaching the Prophet Muhammed. It represents the generations of Prophets, Kaliphs, Shāhs, Padishāhs, Meliks, Suțāns, Imāms and their succession on the throne.

The MS No. 656 is a manuscript of the $18^{\text {th }}$ century entitled Book of Feasts (ضيافت نامه). It contains the descriptions of traditional celebrations devoted to Ottoman Sulțāns and official figures ${ }^{14}$.

The MS No. 1096 contains The List of Baiburt Library ( باييورت كتبخانه سنا (كتب جدولى). It was written in Baiburt by Ahmed Ziyā ud-Dīn. The number of the book or the manuscript, its title, quantity, volume, script and number of lines are noted in regular order. Books and manuscripts are ranged according to themes, with notes about the number of pieces and volumes.

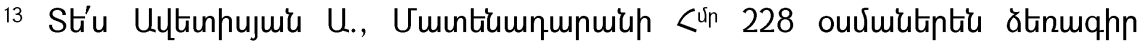
quiluquiumqhnn, Fu'uptin Umintiumnupuiuh, 2014, 20, t, 137-151:

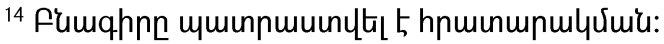


There are about forty bilingual and trilingual miscellanies which contain Ottoman Turkish-Persian, Ottoman Turkish-Arabic, Arabic-Persian, Persian-Ottoman Turkish-Arabic diverse works and texts without the date and name of copyist.

Thirty two miscellanies of this kind had been already described and catalogued; their main languages are Persian and Ottoman Turkish. Those are MSS NN 55, 252, 371, 528, 577, 658, 660, 741, 779, 848, 872, 937, 939, 965, 1035, 1147, 1221, 1234, 1235, 1449 and etc ${ }^{15}$.

Some Ottoman Turkish works included in these above mentioned manuscripts, can be examined here.

Thus, the MS No. 252 entitled Derbend Nāmeh, History of Daghestan (كتاب دربند نامه با احوالات داغستان از اقرار تاريخ), is concluded three different manuscripts in Persian, Arabic and Ottoman Turkish. The Ottoman Turkish version includes the history of all the events occurred in Derbend (Daghestan) from its foundation up to AH 115/AD 753-754. It finishes with the description of the campaign to Derbend of Ebu Muslim ibn 'AbdulMalik. The manuscript was copied in AH 1269/AD 1852-1853 by Mullah Mirzā 'Ali Efendi al Shehir (Colophone, 41a).

The MS No. 660 contains an incomplete copy of Mạ̣būb ul-Kulūb (Dear Hearts) by Mrr 'Ali Shīr Nevāi (ff. 129b-175b) (محبوب القلوب), and Poems of Religious content (Terji 'bends, Kașīehs, Na'ts (ff. 176b-189b), copied in AH 1344-1345/ AD 1926-1927 by Muḥammed Ḳāsim (Colophones, ff. 177b, 178a, 180a, 184b, 187b, 188b, 189b).

The MS No. 939 contains the copy of Fetvas (laws) by Ebu' Su' ūd, 'Ali Efendi, Ahmed ibn Kemāl, two Religious Works, Recipes and Talismans (ff. 2a-3a, 2b, 58a, 66b-67a, 68a-71a, 74a, 132b-133a, 136b, 137b-138a, 140a, 140b-143a).

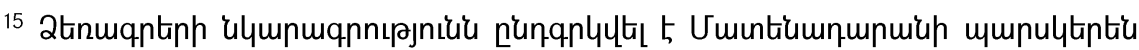

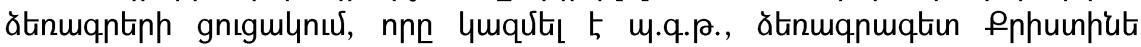
unuunhljuiun:

${ }^{16}$ St'u uny'u pumqnh mJ oph'uml. Rieu Ch., Catalogue of the Turkish Manuscripts in British Museum, Or. 2871, pp. 275-276: 
The MS No. 965 contains an incomplete copy of Divan of Hakiki ( ديوان (حقيقى) (i.e.Karakoyunlu Jihanshāh Ḥakiki (1397?-1467)) (ff. 31b-54b)"17.

The MS. No. 1035 contains the copy of Divan of Fuzūli (كتاب ديوانُ فضولى) (ff. 1b-48b) dated in AH 1065/AD 1654, copied by Ibrāhīm Timur Rumlu 18 (Colophone, 47a); Poem of Leilā and Mejnūn by Fuẓūli ( كتاب ليلى مجنون افصح المتكلمين فضولى بغدادى) (ff. 50b-89b) dated AH 1094 /AD 1681-1682 (Colophone, 89b); and a treatise on the eloquent style called Khațtiyāt min kelām-i Timūrī (خطيات من كلام تيمورى) (ff. 94b - 97b).

The MS No. 848 contains the copy of Gulistān poem (هذا كتاب كلستان)by Sa adī in Persian with underline translation into Ottoman Turkish (ff. 3b114b), made later by Ibrāhīm in AH 1160 /AD 1747 (Colophone, 3a).

We also have to note that parallel to manuscripts description and cataloguing, study is realized as well: MS No. 741 (ff. 108b - 127a), and MS No. 937 (ff. 27b-47b) contain the copies of Persian-Turkish verse dictionaries entitled Tuḥfe-i Shāhidi (تحفه شاهدى) by Turkish poet of the $15^{\text {th }}$ - 16 ${ }^{\text {th }}$ centuries Mughlali Ibrāhīm Shāhidi Dedeh, while MS No. 55 (ff. $73 \mathrm{~b}$ - 96a) and MS No. 983 contain the copies of Persian-Turkish verse dictionaries entitled Tuḥfe-i Sunbul Zādeh or Tuḥfe-i Vehbi (تحفه سنبل زآدم) by Turkish poet and writer of the $18^{\text {th }}$ century Muhammed Sunbul Zãdeh Vehbi. These vers dictionaries have been composed for Persian language teaching in elementary schools. In the MS No. 229 (ff. 2a-7a) we find the work called Old Persian Words Passed into Armenian Language ( ارمنى دلنه (مخلوط اولنوش فرس قديم الفاظلرى (230 is a Persian-Turkish Dictionary by Mirza Muhammed Taghi written in Shūshī; the MS No. 462 is also a Persian-Turkish Dictionary by Kerbelāyi Mullah Muḥammed Ḥusein

17 St'u Úmunuúuu'u, Саакян В., Рукописи «Матенадарана» как источники изучения Туркменской литературы, National Institute of Manuscripts of the Academy of Sciences of Turkmenistan, 2014, 3 (55), стр. 29-37:

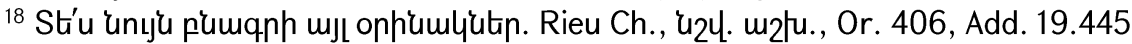
(I. Foll.), Add. 7916, Add. 7917 (I. Foll.), pp. 207-208; Flügel G., 'u24. u2łu., t2 638-639: Zettersteen K. V., Die Arabischen, Persischen und Turkischen Handschriften der Universitätsbibliothek zu Uppsala, Uppsala, 1930, S. 339:

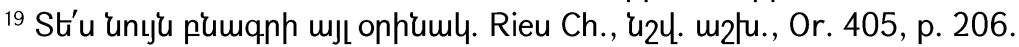


ibn Kerbelāyi Muḥammed written in Lower Najlū in T̄ravān Region.The manuscripts are important especially for their rewritting places ${ }^{20}$.

Thus, very briefly presenting a small part of the Matenadaran Collection of Ottoman Turkish manuscripts, we hope, nevertheless, to have made obvious the scientific value of Ottoman Turkish works as sources for studying the history, literature, religion, jurisprudence, theory of the calendar, medicine and other spheres of Eastern countries and nations ${ }^{21}$.

\section{uчtShUзUน Uนn}

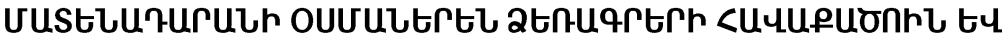

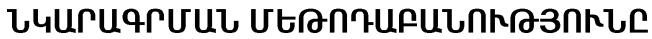

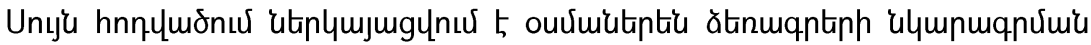

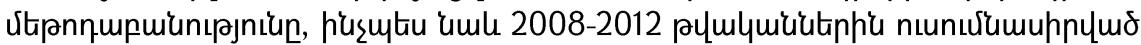

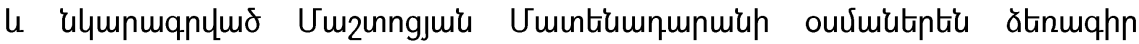

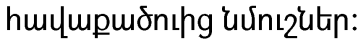

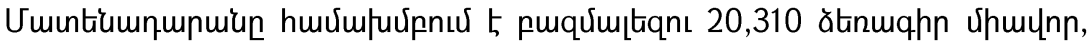

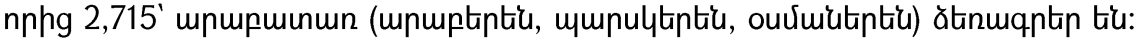

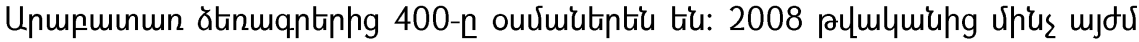

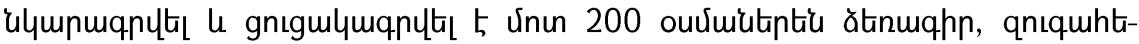

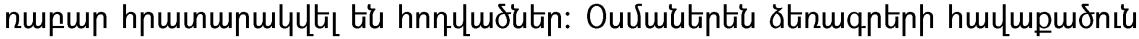

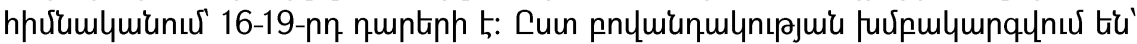

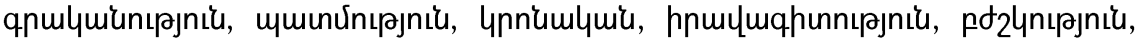

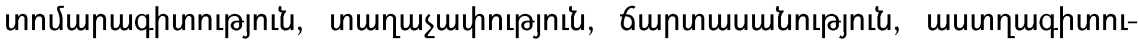

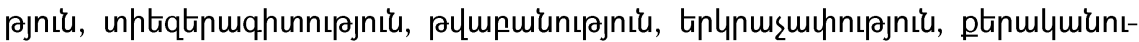

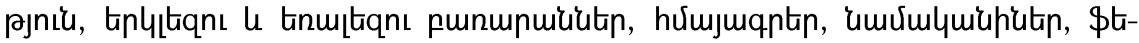

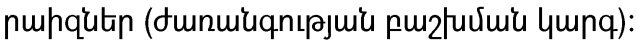

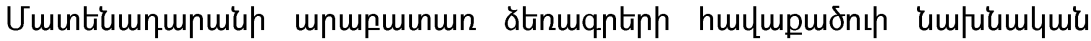

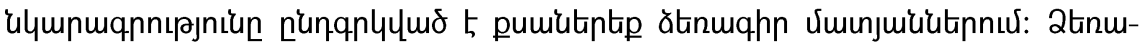

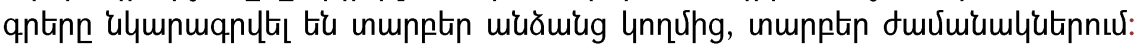

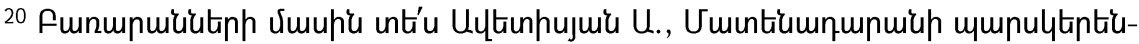

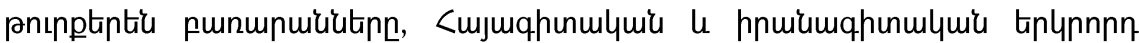

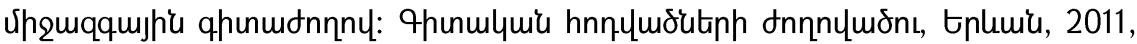
52 148-169: 


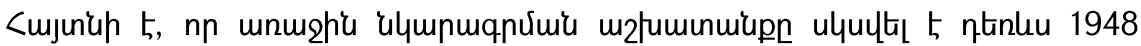

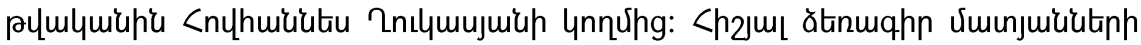

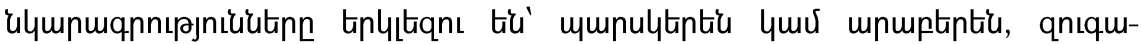

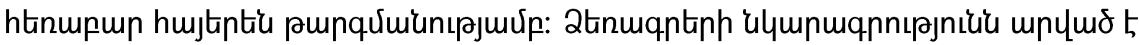

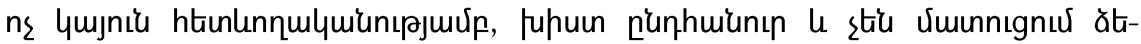

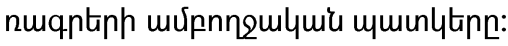

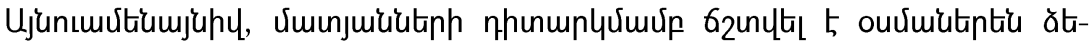

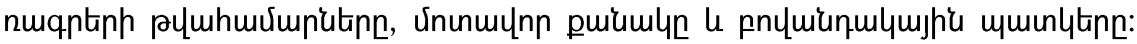

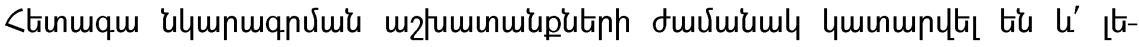
qniutiph, lu' pumqntiph 62unnứtitp:

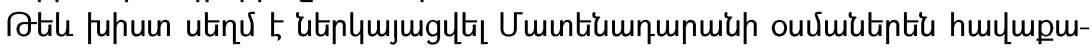

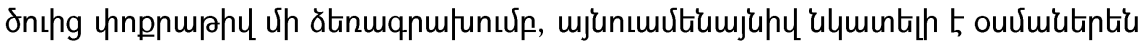

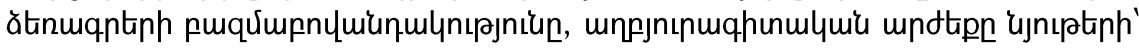

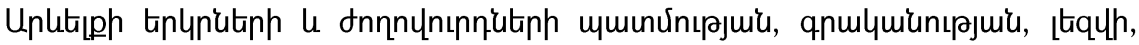

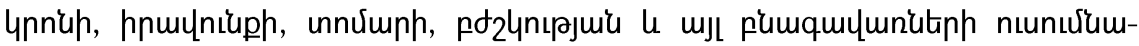
uppnıрjuí hưump: 